\title{
Increased vegetation ground cover reduces water, sediment and phosphorus losses in Cambisol treated with swine slurry
}

\author{
O aumento da cobertura vegetal do solo reduz as perdas de água, sedimentos e fósforo em \\ Cambissolo tratado com dejetos suínos
}
Patrícia Pretto Pessotto ${ }^{1}$ (ORCID 0000-0002-6124-0062), Luciano Colpo Gatiboni2 (ORCID 0000-0001-8724-3600), Daniel João Dall Orsoletta3 (ORCID 0000-0003-0882-0073), Gilmar Luiz Mumbach ${ }^{1}$ (ORCID 0000-0002-1880-3894) ${ }^{\star}$, Daniel Alexandre lochims ${ }^{1}$ (ORCID 0000-0003-4335-6827)

\author{
${ }^{1}$ Santa Catarina State University, Lages, SC, Brazil. *Autor para correspondência: gilmarmumbach@hotmail.com \\ ${ }^{2}$ North Carolina State University, Raleigh, North Carolina, United States of America. \\ ${ }^{3}$ Santa Catarina State University, Chapecó, SC, Brazil.
}

Submission:19/06/2021 | Acceptance: 25/08/2021

\begin{abstract}
This study aims to evaluate the influence of the ground cover rate by crop residues and the rain time elapsed after the application of liquid swine slurry (LSS) under losses of water, sediments, and phosphorus (P). The study was carried out under a Humic Cambisols. Two areas were delimited: with and without the application of LSS. Each area was subdivided into four levels of crop residues: $5 \%, 35 \%, 65 \%$, and $95 \%$. Vegetable residues present in the area, from corn and black oat, were used. Three collecting gutters of $0.60 \mathrm{~m}^{2}$ were installed in each subplot. Simulated rain was carried out on these, and the runoff volume collected for quantification and determination of losses. With LSS application, increase in the cover rate by crop residues reduces $0.3 \mathrm{~mm} \mathrm{~h}^{-1}$ the runoff volume and $1.67 \mathrm{mg} \mathrm{m}^{-2}$ reactive soluble $\mathrm{P}\left(\mathrm{H}_{2} \mathrm{O}-\mathrm{P}\right)$. The sediment losses in the first collection after the beginning of the rain were 23 times lower in the soil with $95 \%$ ground cover than in the soil with $5 \%$ ground cover. The loss of total P (total-P) decreases with the increase of the ground cover of the soil and increases in the same way with the increase of the time.
\end{abstract}

KEYWORDS: runoff, erosion, swine slurry, simulated rain, plant residues.

RESUMO

Este trabalho objetivou avaliar a influência da taxa de cobertura do solo por resíduos culturais e o tempo de chuva decorrido após a aplicação de dejetos líquidos de suínos (LSS) sob perdas de água, sedimentos e fósforo $(P)$. $O$ estudo foi realizado sob um Cambissolo Húmico. Duas áreas foram delimitadas: com e sem aplicação de LSS. Cada área foi subdividida em quatro níveis de resíduos culturais: $5 \%, 35 \%, 65 \%$ e $95 \%$. Foram utilizados resíduos vegetais presentes na área, provenientes de milho e aveia preta. Em cada subparcela foram instaladas três calhas coletoras de $0,60 \mathrm{~m}^{2}$. Sobre estes foi realizada chuva simulada, sendo o volume de enxurrada coletado para quantificação e determinação das perdas. Com a aplicação de LSS, o aumento da taxa de cobertura por resíduos culturais reduziu em $0,3 \mathrm{~mm} \mathrm{~h}^{-1}$ o volume do escoamento e em $1,67 \mathrm{mg} \mathrm{m}^{-2}$ de $\mathrm{P}$ solúvel reativo $\left(\mathrm{H}_{2} \mathrm{O}-\mathrm{P}\right)$. As perdas de sedimento na primeira coleta após o início da chuva foram 23 vezes menores no solo com $95 \%$ de cobertura do que no solo com $5 \%$ de cobertura. A perda de $\mathrm{P}$ total ( $\mathrm{P}$ total) diminui com o aumento da cobertura do solo e aumenta da mesma forma com o aumento do tempo.

PALAVRAS-CHAVE: escoamento, erosão, dejeto suíno, chuva simulada, resíduos de plantas.

\section{INTRODUCTION}

The state of Santa Catarina (SC) is the largest Brazilian producer of swine in Brazil, being responsible for $27.9 \%$ of the total production (ABPA 2019). In this scenario, the high amount of waste generated, called the liquid swine slurry (LSS), associated with the predominantly steep relief (MARTINI 2012, GUERINI FILHO et al. 2015), generate environmental concerns, especially due to the possible contamination of soil and water by chemical elements (COUTO et al. 2015, GATIBONI et al. 2015, BOITT et al. 2018).

The main way of discarding the LSS generated in SC is the soil, due to its potential for nutrient supply to plants (ANTEZAN et al. 2016). However, applications made without technical criteria may exceed the 
nutritional demand of the cultivated species and increase the concentration of chemical elements in the soil (BOITT et al. 2018). Among the elements that generate the greatest concern are phosphorus $(P)$, which is essential to plants and has a great affinity to soil particles (BOITT et al. 2018, BORTOLUZZI et al. 2015). Continued application of this nutrient may reduce P's affinity to soil particles (COUTO et al. 2015, GATIBONI et al. 2015, BOITT et al. 2018) and cause water losses, causing problems such as eutrophication (CHEROBIM et al. 2017).

The superficial application of $\mathrm{P}$, common when the LSS is used, can lead to substantial P losses by surface runoff (BAKER et al. 2017). In the same sense, in soils under no-tillage system (NT) there may be formation of a strong superficial gradient of $P$. In that situation $P$ accumulated in more labile forms and it is more susceptible to the transfer to surface and subsurface waters (GATIBONI et al. 2015, GATIBONI et al. 2021). Intense rainfall events, especially after the application of organic waste, may cause representative losses of chemical elements (GEBLER et al. 2014).

Despite the potential accumulation of $P$ in more superficial layers, soils under NT may present varying $\mathrm{P}$ losses, due to the soil coverage rate (McCONNELL et al. 2013, KHAN et al. 2016). Accumulation can occur in different fractions, with the fraction soluble in water being the most readily susceptible to losses (GATIBONI et al. 2021). The accumulation of crop residues on the surface can reduce the rate and speed of sediment losses, which are potential $\mathrm{P}$ carriers, mainly by reducing the kinetic energy of rain (EI KATEB et al. 2013, KHAN et al. 2016, SCHICK et al. 2017), optimizing the process of water infiltration into the soil profile. The efficiency of the cultural residues in controlling losses of sediments, nutrients and increasing water infiltration in the soil has a direct relation to the type of residue, percentage of ground cover, amount of residue on the area, the adopted management of the area and stage of the plant residues decomposition (EI KATEB et al. 2013). On the other hand, even with the soil cover by crop residues, there are still losses of sediment and nutrients, because with the prolongation of the rains there are increases in the loss rates of smaller sediments (BERTOL et al. 2010, SHARPLEY 2016), which have higher P retention capacity.

The objective of the study was to evaluate the influence of ground cover by crop residues and rainfall time elapsed on water, sediments and $\mathrm{P}$ forms losses after application of LSS in an area under no-tillage system.

\section{MATERIAL AND METHODS \\ Place of study and experiment description}

The study was carried out at the experimental farm of the Santa Catarina State University (UDESC), Santa Catarina state $\left(27^{\circ} 44^{\prime} 54^{\prime \prime} \mathrm{S}, 50^{\circ} 05^{\prime} 08^{\prime \prime} \mathrm{W}\right.$, and 884 meters of altitude), in 2018 . The climate of the site is classified as $\mathrm{Cfb}$ according to the classification of Köppen, with mild summer and well distributed rainfall throughout the year (PEEL et al. 2007). The soil is classified as Humic Cambisols (WRB 2014) and the area has an average slope of $10 \%$.

The area was cultivated until 2018 with black oat in winter, for ground cover, and corn in summer, for grains production. In September 2018 the black oat was dried and at the end of October the experiment was installed. Two areas of the land were delimited, one consisting of the application of swine slurry (with LSS) and another control, without application (without LSS). Each was subdivided into four levels of ground cover: $5 \%, 35 \%, 65 \%$ and $95 \%$. The ground cover levels were created before the application of the LSS, and visually defined by the removal of crop residues from the corn crop and remaining oats in the experimental area to the desired level. The plots with $95 \%$ ground cover did not have residue removal, this being the ground cover rate found in the area. There was no type of soil disturbance maintaining the soil structure in all treatments.

The application of LSS was performed in November of 2018, being applied around $150 \mathrm{~m}^{3} \mathrm{ha}^{-1}$ of LSS. The applied LSS contained $2.9 \mathrm{~kg} \mathrm{~m}^{-3}$ of $\mathrm{P}_{2} \mathrm{O}_{5}, 1.9 \mathrm{~kg} \mathrm{~m}^{-3}$ of $\mathrm{K}_{2} \mathrm{O}, 4.9 \mathrm{~kg} \mathrm{~m}^{-3}$ of $\mathrm{N}, 2.7 \mathrm{~kg} \mathrm{~m}^{-3}$ of $\mathrm{Ca}$, and 1.2 $\mathrm{kg} \mathrm{m}^{-3}$ of Mg. Before LSS application and rain simulation, the soil was collected in the $0-10 \mathrm{~cm}$ layer for chemical characterization. The main results were: 5.32 and $5.43 \mathrm{pH} \mathrm{H} \mathrm{H}_{2} \mathrm{O}, 5.73$ and $5.72 \mathrm{pH}$ TSM (TOLEDO et al. 2012), 2.49 and 2.22\% MO, 42.37 and $21.31 \mathrm{mg} \mathrm{dm}^{-3}$ of $\mathrm{P}, 196.0$ and $73.5 \mathrm{mg} \mathrm{dm}^{-3}$ of $\mathrm{K}, 8.95$ and 5.75 cmolc $\mathrm{dm}^{-3}$ of $\mathrm{Ca}, 5.72$ and $4.62 \mathrm{cmol}_{\mathrm{c}} \mathrm{dm}^{-3}$ of $\mathrm{Mg}$ and 0.26 and $0.31 \mathrm{cmolc}_{\mathrm{cm}}^{-3}$ of $\mathrm{Al}$, considering the soil that received LSS and the soil that did not receive fertilization, respectively. The analyzes of the chemical characterization of LSS and soils with and without LSS were performed according to the methods described by TEDESCO et al. 1995.

The swine manure was collected in a farm with a confinement rearing system, in finishing cycle animals. In the experimental area, the waste was manually distributed in the plots, with the help of a watering can. 
In November 2018, five days after the LSS application, three collecting rails were installed. They have dimensions of $1.00 \mathrm{~m}$ in length by $0.60 \mathrm{~m}$ in width, totaling $0.60 \mathrm{~m}^{2}$ in each subplot (Figure 1A). The rails were installed within the actuation angle of the rain. Simulated rain was performed by means of a portable rain simulator built in the Center of Agricultural Sciences, consisting of a metallic structure, coupled to a motopump, having at the end a fulljet nozzle $(1 / 2 \mathrm{HH}-50 \mathrm{WSQ}$ ) at $3 \mathrm{~m}$ high of the surface of the soil (Figure 1B). The droplet size was similar to that of natural rain, obtained by the flour test according to the method described in MONTEBELLER et al. (2001), where the mean diameter of $50 \%$ of drops varied from 1.90 to $2.60 \mathrm{~mm}$. For each experimental unit, rain lasted 60 minutes and intensity was approximately $67 \mathrm{~mm} \mathrm{~h}^{-1}$. Rain intensity was measured through collectors installed in the spaces between the collectors. The collecting rails directed the runoff of the surface runoff to a collecting container from which a sample was taken every 10 min along the rain, until one hour was completed.
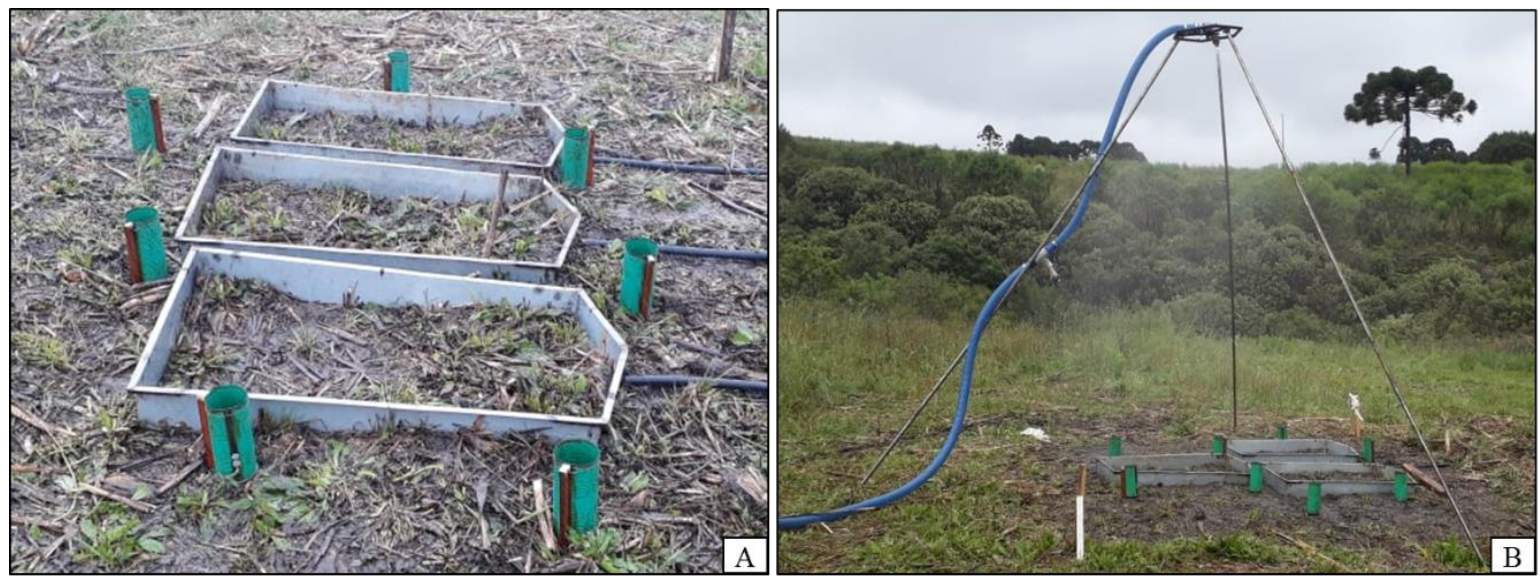

Figure 1. Partial view of: A) collecting rails; B) Rain simulator.

\section{Evaluations}

The total volume drained was determined in the field from the measurement of the water in the collectors, using a testing tube. Runoff samples of approximately $250 \mathrm{~mL}$ were collected to quantify the fractions of reactive soluble $\mathrm{P}\left(\mathrm{H}_{2} \mathrm{O}-\mathrm{P}\right)$, total $\mathrm{P}$ (total- $\mathrm{P}$ ) and lost sediments. $\mathrm{H}_{2} \mathrm{O}-\mathrm{P}$ was valued from the solution by filtration of $15 \mathrm{~mL}$ of the suspension drained in cellulose acetate membrane $(0.45 \mu \mathrm{m})(4500-P$; APHA, 2005). The total-P was extracted, briefly, as follows: $10 \mathrm{~mL}$ of the samples were added to digestion tubes; $1 \mathrm{~mL}$ of $\mathrm{H}_{2} \mathrm{SO}_{4} 30 \%$ and $0.5 \mathrm{~g}$ of $\mathrm{K}_{2} \mathrm{~S}_{2} \mathrm{O}_{8}$ were added; after that, the samples were autoclaved for 30 minutes under a pressure of $120 \mathrm{kPa}$; when at room temperature the volume of the samples was measured to $20 \mathrm{~mL}$ (4500-P; APHA, 2005). P adsorbed to sediment particles, in organic forms and, or, non-reactive forms to the colorimetric method (particulate- $\mathrm{P}$ ), was obtained by the difference between total- $\mathrm{P}$ and $\mathrm{H}_{2} \mathrm{O}-\mathrm{P}$ (LOURENZI et al. 2015). The concentration of $P$ is shown based on the total fraction of the element. $P$ concentration in $\mathrm{H}_{2} \mathrm{O}-\mathrm{P}$ and total- $\mathrm{P}$ extracts was determined by molecular absorption spectrophotometry at a wavelength of $882 \mathrm{~nm}$, according to the method described by MURPHY \& RILEY (1962).

The sediments concentration was estimated by measuring turbidity in $10 \mathrm{~mL}$ aliquots of the drained suspension, in a Digimed TB-1000P bench turbidimeter. The method is based on the light backscattering, resulting in data in a unit of turbidity (NTU) (MINELLA et al. 2008). For this purpose, a calibration curve was created with the soil layer of $0.00-0.10 \mathrm{~m}$ of each area, with or in the application of LSS, for conversion of NTU to $\mathrm{g} \mathrm{L}^{-1}$. Subsequently, the total amount of sediment lost was determined by multiplying the runoff volume by the sediment concentration. Additionally, $\mathrm{P}$ concentration in sediments was estimated by particulate-P division due to the amount of lost sediments.

\section{Statistical Analysis}

The data were evaluated according to the assumption of normality by the Kolmogorov Smirnov test, and transformed by the logarithmic function $(\log X+1)$ to meet this assumption, except for the drained volume. Subsequently, they were submitted to analysis of variance (ANOVA), for the split-plot design, with three replications and repeated measures in time. Fertilization, with or without LSS, was allocated in the main plot and ground cover rates in the subplots, with each experimental unit being evaluated in six times. The significant effects were broken down by regression when ground cover rate or time. The interactions between time and ground cover rate, when significant, were broken down by multiple regression, using the "backward stepwise" solution. The original data were used for the results interpretation. 


\section{RESULTS}

\section{Loss of water and sediments}

The runoff water was influenced by the interaction between the ground cover rate and the time after the rain began (Figure 2). With the increase of one percentage unit in the ground cover rate, there was a reduction of $0.3 \mathrm{~mm} \mathrm{~h}^{-1}$ in the runoff, and an increase of $0.6 \mathrm{~mm} \mathrm{~h}^{-1} \mathrm{~min}^{-1}$ after the beginning of the rain. Considering the first evaluation, $10 \mathrm{~min}$ after the beginning of the rain, we have found that for the $5 \%$ ground cover, there was a runoff of $30.7 \mathrm{~mm} \mathrm{~h}^{-1}$, compared to only $3.7 \mathrm{~mm} \mathrm{~h}^{-1}$ when the ground cover rate was $95 \%$. In other words, for the soil with the lowest ground cover already at the beginning of the rain event, there is runoff of almost $50 \%$ of the precipitated volume, regardless of the application or not of LSS.

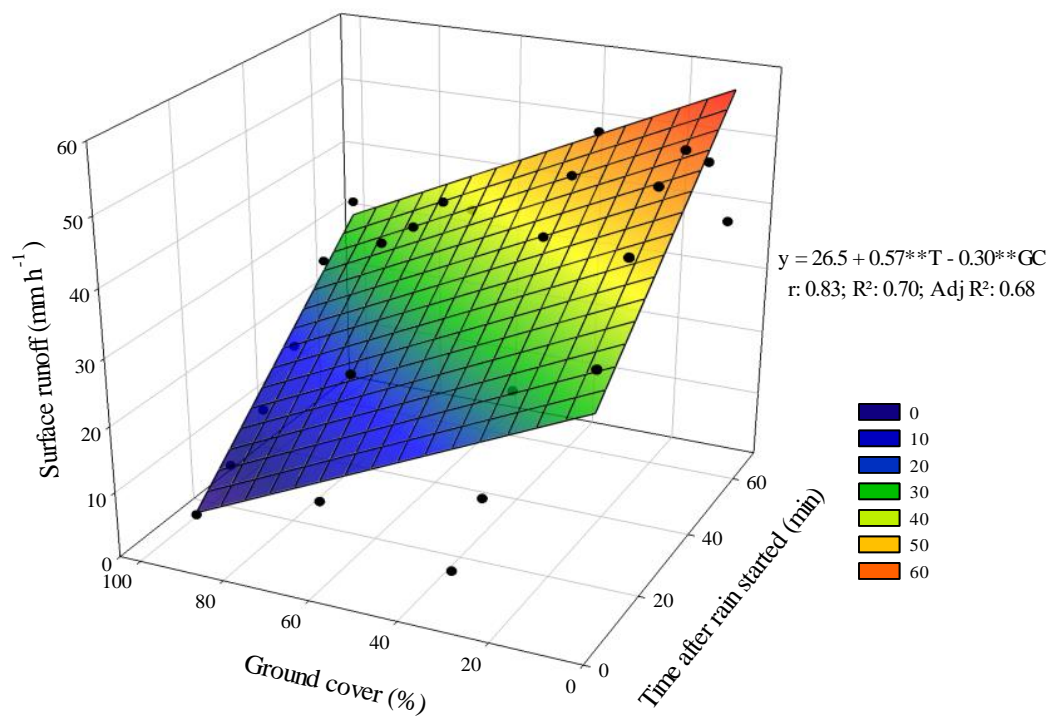

Figure 2. Surface runoff according to ground cover rate (GC) and time after rain started (T) in a Cambisol treated with liquid swine slurry. ${ }^{*}$ Significant by $T$-test $(p<0.01)$

In addition to the reduction in surface runoff, there was also a reduction in the amount of lost sediments due to the increase in the ground cover rate (Figure 3). The highest sediment losses, about $1.8 \mathrm{~kg}$ ha $^{-1}$, occurred in the condition with only $5 \%$ ground cover and in the first sampling after the beginning of the rain. Over time, however, there is a linear decrease in sediments loss in this soil, in a magnitude of $0.02 \mathrm{~kg}$ $\mathrm{ha}^{-1}$ for each minute, reaching values close to the other ground cover conditions at the end of the evaluation period. In the opposite direction, under the highest rate of plant ground cover (95\%), the initial losses are extremely low, 23 times lower than the losses observed with the lowest ground cover rate. However, over time, there is a small increase in sediment losses for this condition, reaching a maximum value of $0.3 \mathrm{~kg} \mathrm{ha}^{-1}$ after 55 minutes. It should be noted that, after 60 minutes of evaluation, sediment losses were equivalent among the different ground cover rates.

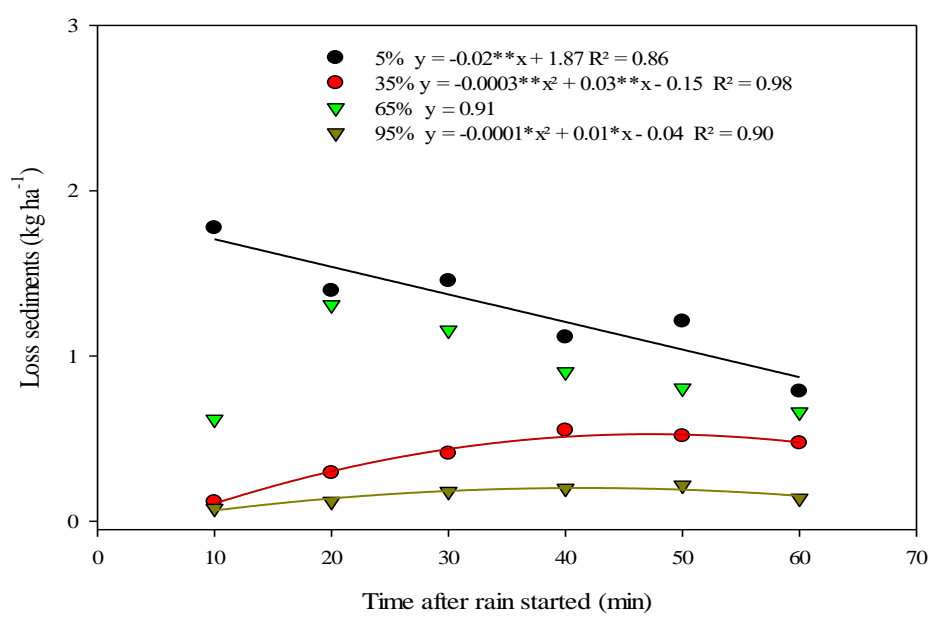

Figure 3. Loss sediments according to the ground cover rate and time after rain started in a Cambisol treated with liquid swine slurry. ${ }^{*}$ Significant by $T$ test $(P<0.05) ;{ }^{* *}$ Significant by $T$ test $(p<0.01)$ 


\section{P-form losses}

The phosphorus concentration in the sediments was influenced by the ground cover rate, the time after rain started, and the application or not of LSS (Figure 4). With fertilization (Figure 4A), the ground cover rate has an ambiguous effect, reducing the $\mathrm{P}$ concentration in the sediment in the first few moments after the beginning of the rain until approximately 30 minutes, when there is a nullity of effect. Later, the ground cover rate begins to have an opposite effect, contributing to the increase in $\mathrm{P}$ concentration in the sediments. In the condition without the application of LSS (Figure 4B), the P concentration in the sediments is significantly lower than the condition that received LSS.
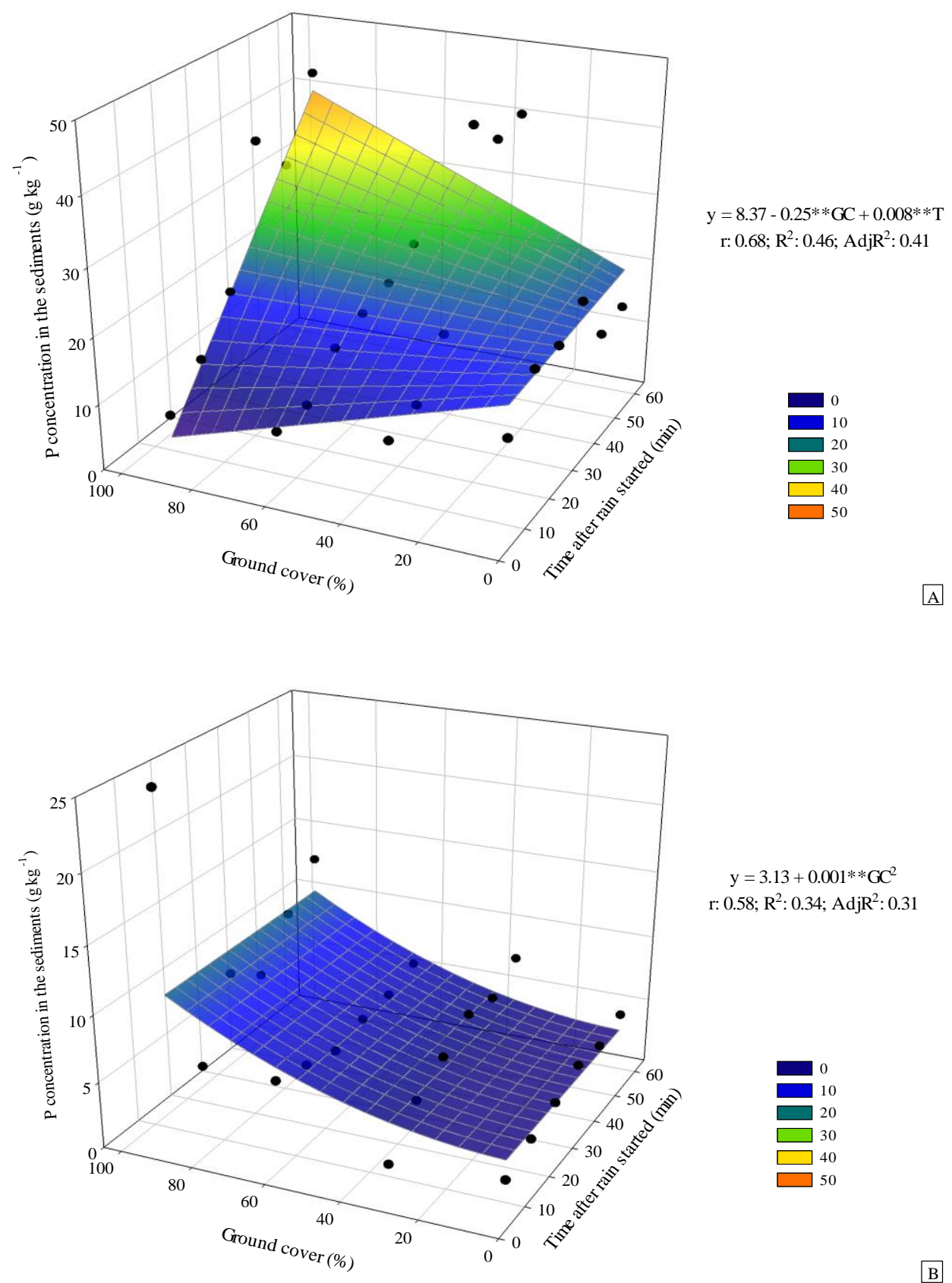

Figure 4. Phosphorus concentration in the sediments in function of the time after rain started $(T)$ and the plant ground cover rate (GC), for: A) soil with LSS and B) soil without LSS. ** Significant by the Ttest $(p<0.01)$.

The application of LSS increased the total-P losses by approximately six times (from 41.5 to $234.9 \mathrm{mg}$ $\mathrm{m}^{-2}$ ), compared to the area without application. The loss of total-P decreases in a quadratic form with the increase of the ground cover and increases with the rain time (Figure 5). As the maximum ground cover rate, in a completely ground cover soil, it is possible to infer that there will be a reduction in total-P losses of 150 $\mathrm{mg} \mathrm{m}^{-2}$, depending on the soil protection regardless of the time elapsed. 


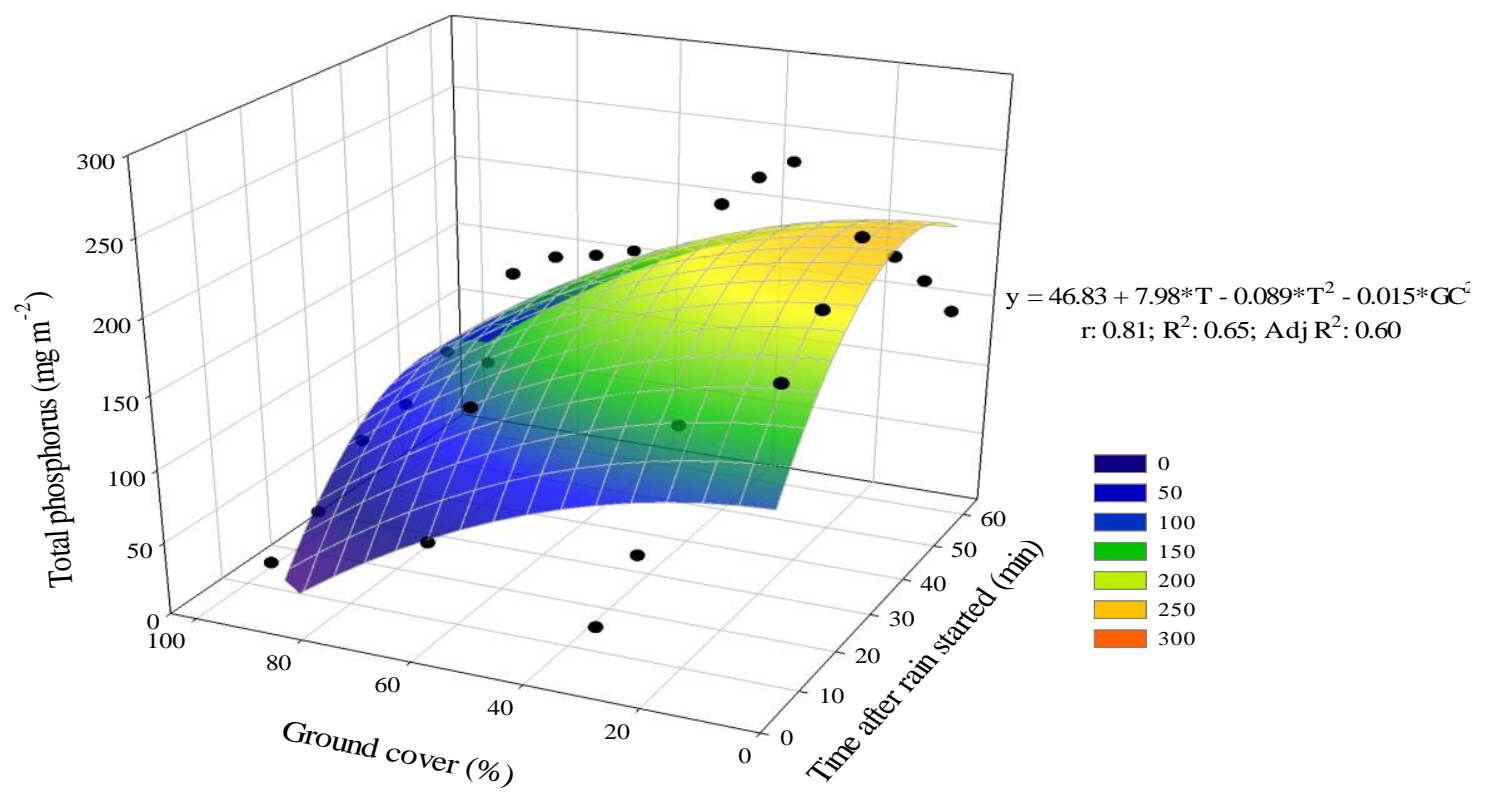

Figure 5. Total phosphorus loss in function of ground cover rate $(\mathrm{GC})$ and the time

For the loss of reactive dissolved phosphorus $\left(\mathrm{H}_{2} \mathrm{O}-\mathrm{P}\right)$, there is a reduction of $1.67 \mathrm{mg} \mathrm{m}^{-2}$ for each percentage increment of ground cover when LSS is applied (Figure 6). On the other hand, time shows quadratic behavior, with a maximum loss of $\mathrm{H}_{2} \mathrm{O}-\mathrm{P}$ at approximately $45 \mathrm{~min}$ after the beginning of the rain, and subsequent reduction. When there is no application of LSS, the $\mathrm{H}_{2} \mathrm{O}-\mathrm{P}$ loss is constant due to time and ground cover rate, with an average of $12.8 \mathrm{mg} \mathrm{m}^{-2}$.

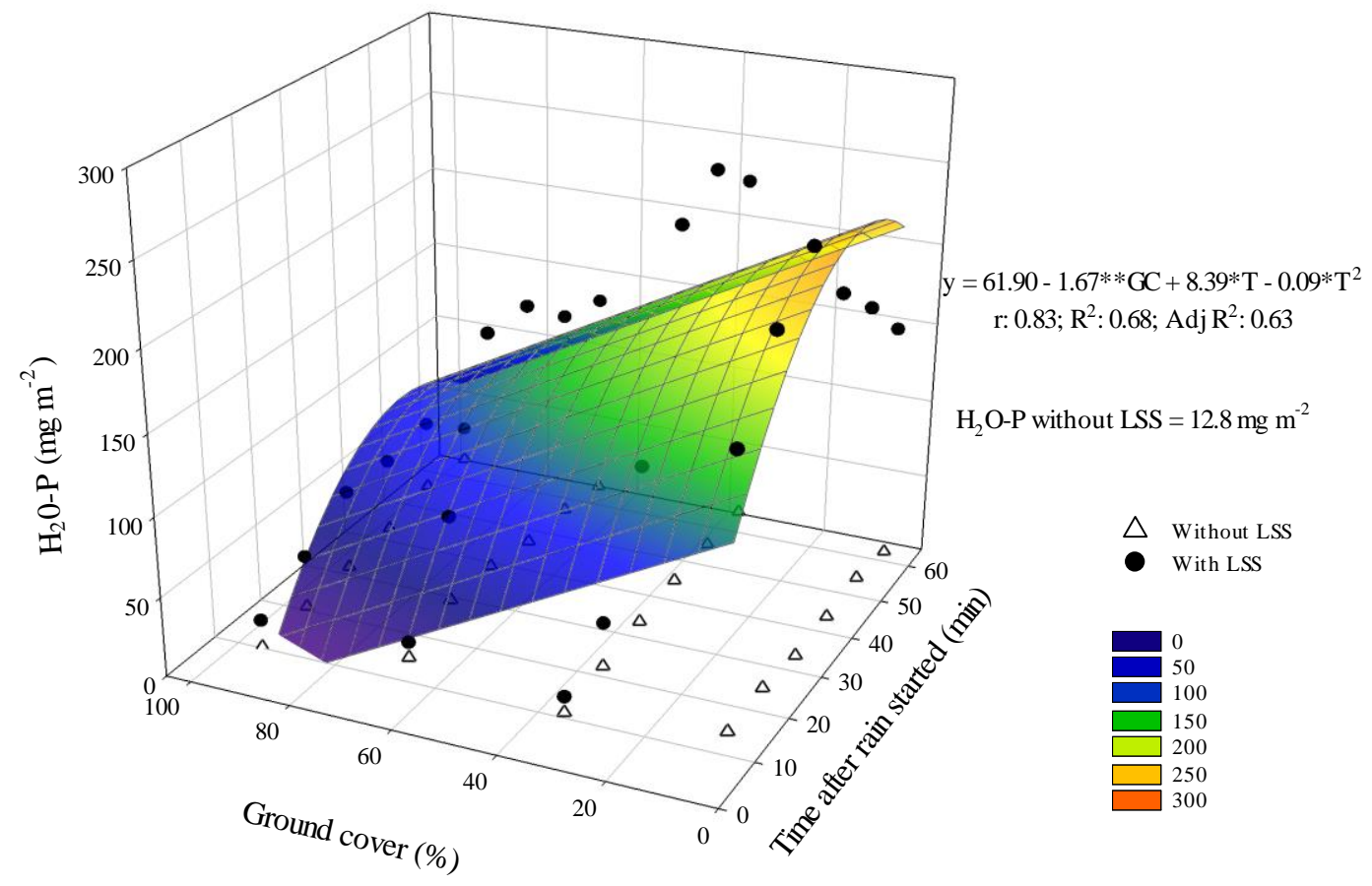

Figure 6. Loss of reactive dissolved phosphorus $\left(\mathrm{H}_{2} \mathrm{O}-\mathrm{P}\right)$ in function of the ground cover rate $(\mathrm{GC})$ and time after rain started $(T)$ in a Cambisol treated with liquid swine slurry. *Significant by $T$ test $(P<0.05)$; ${ }^{* *}$ Significant by $T$ test $(p<0.01)$.

The amount of particulate $P$ lost was influenced by the rate of plant ground cover and the rain elapsed time (Figure 7). Particulate $P$ losses increase linearly as a function of time, with a magnitude of $0.8 \mathrm{~g} \mathrm{~m}^{-2} \mathrm{~min}^{-}$ 1 regardless of ground cover rate. On the other hand, the ground cover rate has a quadratic effect on losses. In this sense, imagining that the maximum ground cover that can be achieved is $100 \%$, a fully ground cover could reduce particulate-P losses by up to $70 \mathrm{~g} \mathrm{~m}^{-2}$. With this, the amount lost being conditioned exclusively to the duration of the rain event. 


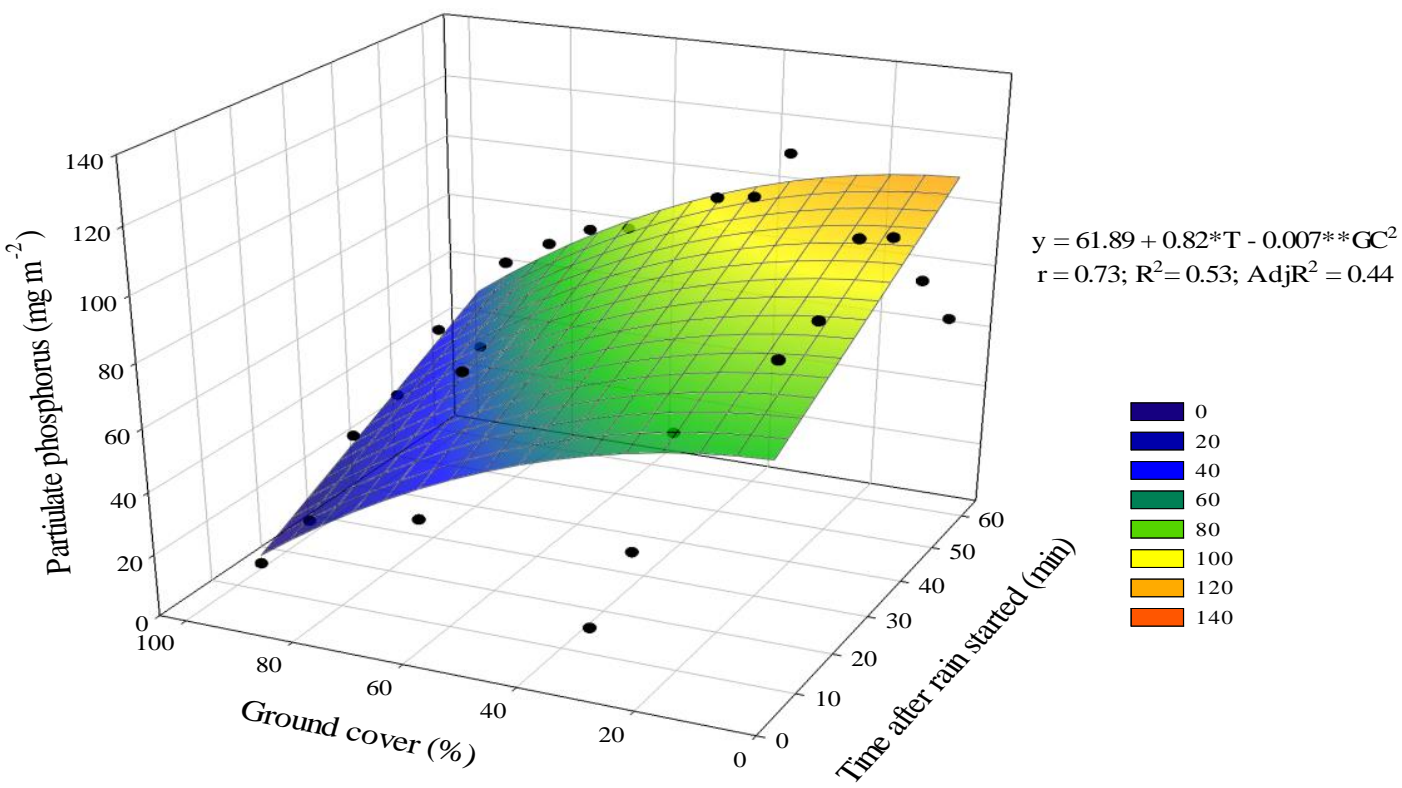

Figure 7. Particulate phosphorus loss in function of the ground cover rate (GC) and time after rain started (T) in a Cambisol treated with liquid swine slurry. ${ }^{*}$ Significant by $\mathrm{T}$-test $(\mathrm{P}<0.05) ;{ }^{* *}$ Significant by $\mathrm{T}$-test $(p<0.01)$.

\section{DISCUSSION}

Soil cover with plant residues positively influenced most of the variables evaluated, reducing water, sediment and $P$ forms losses. The presence of plant residues on the soil surface has fundamental importance to soil quality conservation (EI KATEB et al. 2013). Plant residues are recommended as one of the main pillars of the No-till System (NT), bringing benefits that go far beyond those evaluated in this study.

The increased soil cover with crop residues reduces the drained volume (Figure 2), as it increases the roughness of the ground and thus the surface water retention in the soil (WANG et al. 2017, HARUNA et al. 2018). Higher land cover rates are reflected in higher water infiltration rate and smaller runoff volumes, as well as longer runoff time. (MCLAUGHLIN \& BROWN 2006, El KATEB et al. 2013, KHAN et al. 2016). Even so, the total drained volume will still be conditioned at the time and intensity of the rains, because there is a limit capacity for water absorption for each soil; at this level, water runoffs under the ground, regardless of the rate and type of ground cover (SCHICK et al. 2017).

In addition, the plant wastes on the soil dissipates the kinetic energy of the rain drop, minimizing soil disaggregation and, consequently, the amount of sediment that can be transported by surface runoff (EI KATEB et al. 2013, KHAN et al. 2016, SCHICK et al. 2017). At the same time, there is a reduction in the velocity of the surface runoff, increasing the time available for the deposition of the largest and most dense sediments (BERTOL et al. 2010), drastically minimizing their losses. Furthermore, higher land cover rates result in lower sediment loss rates (Figure 3) and smaller diameter of lost sediment. SCHICK et al. (2017), assessing soil erosion conducted at 20 years under different management systems, observed that under NT, the water and sediment losses were 2.7 and 7.8 times lower than those observed in conventional tillage and 4.2 and 104.0 times lower than those observed in bare soil, respectively. According to these authors, the lowest influence of the soil management system on the volume of drained water, in comparison to that observed for sediment losses, is due to the threshold of the basic infiltration rate, a characteristic that does not depend on the use of the soil, or ground cover.

As the surface runoff time goes by, it decreases the amount of sediments of larger and denser diameter, but it increases the amount of sediment of smaller diameter lost and, consequently, increases the risk of environmental contamination (BERTOL et al. 2010, GEBLER et al. 2014, SHARPLEY 2016). Since the smallest diameter particles, especially those of the clay fraction, are responsible for the higher content of adsorbed P (GEBLER et al. 2014). This increase, of the sediments losses of smaller diameter over time may justify the increase in $\mathrm{P}$ concentration in sediments observed in this study (Figure 4). In the lower evaluated ground cover condition, the $\mathrm{P}$ concentration in the sediments is more balanced according to the time, probably due to the lower particle segregation per size. With the increase in the ground cover rate, however, there is a preferential loss of coarse and less P-rich sediments at the beginning of the runoff, and later, there is a loss of smaller and P-rich sediments. 
Soil enrichment with $\mathrm{P}$ is common to areas where LSS is applied, commonly performed superficially, promoting $P$ enrichment on the soil surface where losses by runoff are susceptible (BOITT et al. 2018). Additionally, the solid LSS, which have a low density and are easily loaded by runoff, are rich in P. In this scenario, the first rain events after LSS application present a high risk of P losses (GEBLER et al. 2014, CHEROBIM et al. 2017), which, in addition to economic damage, increases the risk of environmental contamination (BOITT et al. 2018, GEBLER et al. 2014). Thus, it is evident that soils with superficial application of LSS will be prone to higher $\mathrm{H}_{2} \mathrm{O}-\mathrm{P}$ losses than soils without this application, even if they present high $\mathrm{P}$ levels, as in the present study.

The preferential loss of colloidal particles by the runoff (RAMOS et al. 2016), ends up resulting in more concentrated particle losses, with phosphorus enrichment in the lost sediment (BORDA et al. 2014) and consequently greater loss of total $P$. Particulate- $P$, chemically adhered to sediments, may represent more than $80 \%$ of total lost $P$ (WITHERS et al. 2009, BORDA et al. 2011).

The present study demonstrates the importance of the presence of plant ground cover on the soil surface is indisputable. Thus, the application of LSS, as well as the broadcast mineral fertilizer, in conservative agricultural systems, without soil tillage, should be carried out in the presence of good plant ground cover on the soil. Under these conditions, the risks of nutrient loss and environmental pollution are minimized.

\section{CONCLUSION}

The increase in the ground cover rate is an effective practice to reduce losses of water, sediment and P fractions.

The highest ground cover rate reduces the $\mathrm{P}$ concentration in sediments in the first moments after the rain started, but an increase in this parameter is observed in the course of time.

With the increase in rainfall time, water and $\mathrm{P}$-fraction losses are increased, with a reduction in $\mathrm{P}$ soluble and P-total losses from 45 minutes after rain started. Sediment losses increase as a function of time for ground cover rates from 35 to $95 \%$ and decrease for rates of $5 \%$.

\section{REFERENCES}

ABPA. 2019. Associação Brasileira de Proteína Animal. Relatório Anual da ABPA. http://abpa-br.org/relatorios. Acesso em: 03 mar. 2020.

ANTEZAN AW et al. 2016. Composition, potential emissions and agricultural value of pig slurry from Spanish commercial farms. Nutr Cycl Agroecosys 104: 159-173.

APHA. 2005. American Public Health Association. Standard methods for the examination of water \& wastewater. 21 ed. Washington: American Public Health Association. 1274p.

BAKER DB et al. 2017. Vertical Stratification of Soil Phosphorus as a Concern for Dissolved Phosphorus Runoff in the Lake Erie Basin. J Environ Qual 46: 1287-1295.

BERTOL I et al. 2010. Sedimentos transportados pela enxurrada em eventos de erosão hídrica em um Nitossolo Háplico. Rev Bras Cienc Solo 34: 245-252.

BOITT G et al. 2018. Fate of phosphorus applied to soil in pig slurry under cropping in Southern Brazil. Geoderma 321 : 164-172.

BORDA T et al. 2011. Effect of agronomic management on risk of suspended solids and phosphorus losses from soil to waters. J Soil Sediment 11: 440-451.

BORDA T et al. 2014. Fertilization Strategies Affect Phosphorus Forms and Release from Soils and Suspended Solids. J Environ Qual 43: 1024-1031.

BORTOLUZZI EC et al. 2015. Occurrence of iron and aluminum sesquioxides and their implications for the $P$ sorption in subtropical soils. Appl Clay Sci 104: 196-204.

CHEROBIM VF et al. 2017. Tillage system and time post-liquid dairy manure: Effects on runoff, sediment and nutrients losses. Agr Water Manage 184: 96-103.

COUTO RR et al. 2015. Environmental Vulnerability and Phosphorus Fractions of Areas with Pig Slurry Applied to the Soil. J Environ Qual 44: 162-173.

EL KATEB $\mathrm{H}$ et al. 2013. Soil erosion and surface runoff on different vegetation covers and slope gradients: A field experiment in Southern Shaanxi Province, China. Catena 105: 1-10.

GATIBONI LC et al. 2015. Soil Phosphorus Thresholds in Evaluating Risk of Environmental Transfer To Surface Waters in Santa Catarina. Brazil. Rev Bras Cienc Solo 39: 1225-1234.

GATIBONI LC et al. 2021. Phosphorus speciation in soils with low to high degree of saturation due to swine slurry application. J. Environ. Manage 282: 111553.

GEBLER $L$ et al. 2014. Transferência superficial de fósforo reativo potencialmente contaminante por chuvas simuladas intensas. Eng Sanit Ambient 19: 393-399.

GUERINI FILHO M et al. 2015. Análise do Consumo de Água e do Volume de Dejetos na Criação de Suínos. Rev Bras 
Agropecuária Sustentável 5: 64-69.

HARUNA SI et al. 2018. In situ infiltration as influenced by cover crop and tillage management. J Soil Water Conserv 73 : 164-172.

KHAN MN et al. 2016. Effect of Slope. Rainfall Intensity and Mulch on Erosion and Infiltration under Simulated Rain on Purple Soil of South-Western Sichuan Province, China. Water 8: 528-546.

LOURENZI CR et al. 2015. Forms of phosphorus transfer in runoff under no-tillage in a soil treated with successive swine effluents applications. Environ Monit Assess 187: 209.

MARTINI LCP. 2012. Características morfométricas de microbacias hidrográficas rurais de Santa Catarina. Revista Brasileira de Geomorfologia 13: 65-72.

MCCONNELL DA et al. 2013. The impact of herbage re-growth interval on phosphorus losses in runoff post slurry application. Agriculture Ecosystems and Environment 178: 100-108.

MCLAUGHLIN RA \& BROWN TT. 2006. Evaluation of erosion control products with and without added polyacrylamide. J Am Water Resour As 42: 675-684.

MINELLA JPG et al. 2008. Estimating suspended sediment concentrations from turbidity measurements and the calibration problem. Hydrol Process 22: 1819-1830.

MONTEBELLER CA et al. 2001. Avaliação hidráulica de um simulador de chuvas pendular simulador de chuvas pendular. Rev Bras Eng Agr Amb 5: 1-5.

MURPHY J \& RILEY JP. 1962. A modified single solution method for the determination of phosphate in natural waters. Anal Chim Acta 27: 31-36.

PEEL MC et al. 2007. Updated world map of the Köppen-Geiger climate classification. Hydrol Earth Syst Sc 11: 16331644.

RAMOS JC et al. 2016. Water erosion in surface soil conditions: runoff velocity concentration and D50 index of sediments in runoff. Sci Agr 73: 286-293.

SCHICK J et al. 2017. Water erosion in a long-term soil management experiment with a Humic Cambisol. Rev Bras Cienc Solo 41: 1-13.

SHARPLEY A. 2016. Managing agricultural phosphorus to minimize water quality impacts. Sci Agr 73: 1-8.

TEDESCO MJ et al. 1995. Análise de solo, plantas e outros materiais. 2.ed. Porto Alegre, UFRGS. 147 p. (Boletim Técnico, 5).

TOLEDO JÁ et al. 2012. Tampão Santa Maria (TSM) como alternativa ao tampão SMP para medição da acidez potencial de solos ácidos. Rev Bras Cienc Solo 36: 427-435.

WANG L et al. 2017. Effects of tillage practices and slope on runoff and erosion of soil from the Loess Plateau, China, subjected to simulated rainfall. Soil Till Res 166: 147-156.

WITHERS PJA et al. 2009. The effect of soil phosphorus on particulate phosphorus in land runoff. Eur J Soil Sci 60: $994-$ 1004.

WRB 2014. World Reference Base for Soil Resources. A framework for international classification, correlation and communication. Food and Agriculture Organization of the United Nations. Rome: IUSS/ISRIC/FAO. (World Soil Resources Reports, 106). 